\title{
Playing House: Staging Experiments About Women in Domestic Space
}

Ann M. Shanahan

ashanah@luc.edu

Follow this and additional works at: https://ecommons.luc.edu/dfpa

Part of the Fine Arts Commons

\section{Recommended Citation}

Shanahan, AM. "Playing House: Staging Experiments About Women in Domestic Space." Theatre Topics 23(2), 2013.

This Article is brought to you for free and open access by the Faculty Publications and Other Works by Department at Loyola eCommons. It has been accepted for inclusion in Department of Fine \& Performing Arts: Faculty Publications and Other Works by an authorized administrator of Loyola eCommons. For more information, please contact ecommons@luc.edu.

\section{(c) $($ ) (2) $\Theta$}

This work is licensed under a Creative Commons Attribution-Noncommercial-No Derivative Works 3.0 License. (c) Johns Hopkins University Press, 2013. 


\title{
Playing House: Staging Experiments About Women in Domestic Space
}

\author{
Ann M. Shanahan
}

The relationship between women and the houses they inhabit has been repeatedly explored in literature and drama, where the house operates as a complex, often contradictory referent for women's social position. The principal location of women's lives through history, a house represents, on the one hand, a space of restrictions and limitation; and on the other, a creative domain. In drama, playwrights have used the setting of a house to inform conflicts surrounding women's freedom, and have manipulated spatial dramaturgy to enrich these subjects. As ongoing experiments in the performance of gender, I am staging a series of workshops in the large mansion that houses the Women's Studies and Gender Studies (WSGS) Program ${ }^{1}$ and the Gannon Center for Women and Leadership at my university. These include a workshop of Ibsen's A Doll's House with undergraduate student actors and a full production of Maria Irene Fornes's Fefu and Her Friends, with faculty from several departments cast in the eight female roles. Both plays concern a house in relation to central female characters, and in both, this relationship is intricately connected to the play's action and its significance. With these projects, I set out to explore the potential of staging in domestic architecture to amplify conflicts concerning women and houses in the plays. I have found, in fact, that staging in a house goes further, to reveal previously obscure dramaturgical aspects of the plays, the dynamics of which, in turn, suggest further explorations in feminist performance-based research, both academic and pedagogical. Potential extensions of these experiments include the use of live performance as a methodology for research on gender for disciplines beyond theatre, such as history and anthropology, and as means of pedagogical innovation and community-building across disciplines.

\section{Women and Houses in Literature}

For centuries, houses have figured large in writing by and about women. This usage became particularly pronounced at the end of the nineteenth century, when the historical restriction of women to the domestic realm was about to change. In A Room of One's Own, Virginia Woolf uses the metaphor of a house both to advocate for female autonomy within domestic space, and to mark that space as a repressive container of female creativity. Woolf illustrates the significance of the domestic space for women in the following passage:

the resources of the English language would be much put to the stretch, and whole flights of words would need to wing their way illegitimately into existence before a woman could say what happens when she goes into a room.... One has only to go into any room in any street for the whole of that extremely complex force of femininity to fly in one's face. How should it be otherwise? For women have sat indoors all these millions of years, so that by this time the very walls are permeated by their creative force. (87)

The same consideration of domestic walls as a site of creativity and repressed authority is explored by other female writers of the same period. In "The Yellow Wallpaper" (1888), Charlotte 
Perkins Gillman tells the story of a woman who merges with decorative features of the house that has become her prison. ${ }^{2}$ Edith Wharton (herself a decorator and designer of houses ${ }^{3}$ ) less directly applies the metaphor in The House of Mirth. Here, the house serves as an abstract symbol for a transitional time in fashionable New York society for women at the end of the nineteenth century. ${ }^{4}$ Wharton's memoirs refers to her own life as an artist as secret rooms-an "inner house":

I have sometimes thought a woman's nature is like a great house full of rooms: there is the hall through which everyone passes in and out and the drawing room where one receives formal visits . . . but beyond that, far beyond, there are other rooms, the handles of whose doors are never turned, no one knows the way to them, no one knows whither they lead; and in the innermost room, the holiest of holies, the soul sits and waits for a footstep that never comes. ${ }^{5}$

In The Poetics of Space: The Classic Look at How We Experience Intimate Places, French philosopher Gaston Bachelard endeavors to articulate the way a house operates on the human psyche: "the house is one of the greatest powers of integration for the thoughts, memories and dreams of mankind. Past, present and future give the house different dynamisms, which often interfere, at times opposing, at others stimulating on another. ... Without it, man would be a dispersed human being. ... Life begins well, it begins enclosed, protected, all warm in the bosom of the house" (7). While (importantly) he refers to "man" as his subject, Bachelard's poetics offers helpful philosophies for our consideration. The imagery of the female body that he uses is common; the house is frequently linked to the female body in symbolism and iconography. ${ }^{6}$

\section{The Subject in Drama}

The literary connection between women and houses is reflected in drama, particularly from the late nineteenth century. Chekov places houses at the centers of his plots alongside pivotal female characters, including Ranevskaya in A Cherry Orchard, the sisters in The Three Sisters, and, less directly, Sonya in Uncle Vanya and Arkadina in The Seagull. Houses and female characters figure large in $A$ Doll's House, Hedda Gabler, The Master Builder, and Ghosts, among several other plays by Ibsen. Of these, $A$ Doll's House is the most significant example of the complex relationship between the female and the domestic space in drama of this period. The action of the play traces Nora's relationship to the house, the final door-slam marking her departure from the space to a life with new options (and conflicts) for women, both onstage and off.

The frequent use of the house as a setting and site of conflict in the dramas of this period is far from coincidental; rather, the presence of the house is significant to the depiction of women onstage, especially as her cultural situation is about to change. In Women's Theatrical Space, Hanna Scolnicov identifies the early realistic period as a move inside a female space hitherto denied by a barrier at the domestic threshold, a historical divisor of oikos and polis since the origins of the Western theatrical tradition in ancient Greece. Scolnicov's argument regarding the separation of theatrical space into male and female is based on the implementation of the skene, and its iconic division between private and public space, oikos and polis, female and male: "The face of the house thus marks the barrier between the genders and it is only on the threshold that man and woman can meet" (13). Since Greek theatre in the fifth century BCE, the domestic space has been relegated unseen, behind the skene doors. It is not until the realistic period that we move entirely indoors into the once private space of the parlor, now shared for the first time by both genders. While this move inside promises fuller expression of feminine subjects onstage, Scolnicov considers it unsatisfactory: "This move indoors which seemed to promise a less restricted view of women's problems by shifting the scene from the threshold and into her own territory turns out to be disappointing. Now the woman becomes hampered by the drawing room itself, retreating to an inner room of her own" (96). Hedda Gabler must move into the upstage inner room housing the portrait of her father, and Nora retreats to her room, where she works in secret to pay back the loan she has from Krogstad and ultimately the 
famous door-slam marks her departure from the box entirely into the uncharted environs of upstage space. The theatrical style of realism, according to Scolnicov, necessitates a retreat of the female even deeper into (or out of) her historically private space (94).

In Feminism and Theatre, Sue-Ellen Case likewise critiques the realism of this period as "a prison house of art for women" (124). Considering the architecture of the proscenium theatre and the apparatus of viewing within it, Case, along with Jill Dolan, Elin Diamond, and others, have argued that the privileged position vis-à-vis a fourth wall invokes a male gaze and colludes with other stylistic features to objectify female characters. A woman's full and authentic expression in performance ultimately forces her to break the fourth wall and shift the traditional mimetic relationship of observer/observed. ${ }^{7}$ Feminist practitioners have employed a variety of tactics to break out of the box sets, climactic plot structures, and performance styles of this period, ${ }^{8}$ rendering Nora's door-slam not only a departure from her marital home, but from a style of performance that can not contain her authentic self.

Observing the significance of the theme of women and houses in drama, I became interested in staging experiments in the house on my university campus. A white stone mansion in the Arts and Crafts style, Piper Hall was designed in large part by its first female occupant, Cassie Wheeler, in 1909. It has been the domestic home to two owners, Albert Wheeler, then Albert Johnson in 1916. In 1934, the house was purchased by Mundelein College, an all-female Catholic college founded in 1930 , and served as its library until the 1960s, then briefly as a student union and home to various academic programs in the 1970s and '80s. After the college was purchased by Loyola University, at the end of the twentieth century, the structure fell into disuse. Then, in 2005, through the fundraising efforts of the Sisters of Charity of the Blessed Virgin Mary the space was restored to its original condition on the first floor, with second and third floor spaces converted to offices and an archive. It was through a Gannon fellowship in 2009 that I undertook staging experiments in the house.

\section{Spatial Dramaturgy of A Doll's House}

Ibsen's titular symbol is not just a metaphor for the cultural location of women at that time, but refers with genius to the theatre itself. The box set, with the removed fourth wall, mimics the architecture of a dollhouse. When Nora leaves the house, she exits upstage, out of the box set and into a world not depicted in the theatre. Thus Ibsen not only sheds light on the repression of women in his culture, but also on the repression of the female subject in the theatre and within the style of realism in which he is writing. Scolnicov considers that "the concrete representation of reality in the theatre is used ironically by Ibsen to destabilize its own message." When the audience discovers that the family home that seems so ideal at the beginning is purchased on deceit, "the house is seen to be a false representation. The misleading appearance of the room alerts the spectator to the falseness of the reality" (94). Role-playing is at the center of the play and Nora's real self is hidden. In order to heal this rift in her personality Nora must leave the house altogether. When she reaches that conclusion, the traditional spatial definitions, social as well as theatrical, are thrown into disarray. The woman's passage out of the home and into the world leaves the male in the house and severs the woman's ties with her home as her unique space (96). According to Scolnicov, Ibsen's symbolic use of space in the play signals to the audience the fact that what is seen does not contain the whole of the story (Fig. 1).

\section{The Workshop}

These considerations of the play's central spatial metaphor resonated interestingly in our experiment. We performed on the first floor exclusively, in the space most like the original family home. The main scenes were played in the large parlor, lined with window seating along two of its 


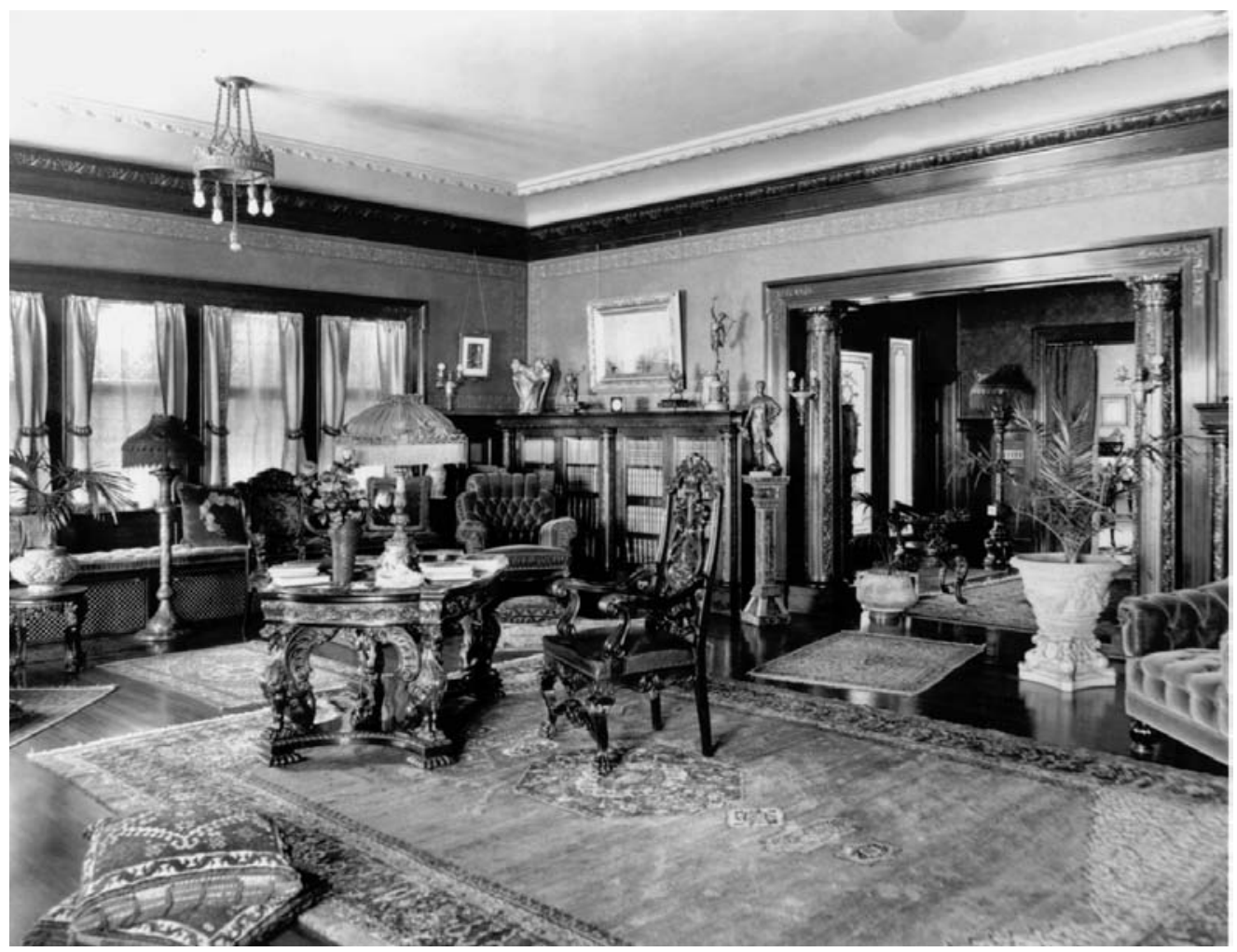

FIG. 1. Piper Hall drawing room during the 1920s. (Photo courtesy of the Women and Leadership Archives, Loyola University Chicago.)

four walls. We used the real front door, answered most often by a maid character. A large library at the other side of the hall with a sliding door served as Torvald's study; a set of double sliding doors at the other side of the parlor was the entrance to the dining room. Servants' entrances from a back pantry allowed the maid to come and go quickly. While the audience remained on the first floor, Nora and the maid traversed the real staircase for the realistic sounds of footsteps and other incidental offstage noises. We focused on staging the entire second act and the crucial conclusion of the third containing the return from the party through Nora's transformation and departure. In this section, Nora faces several moments of "performance" with other characters, and in act 3, we see this performance come to its culmination, threatening the end of Nora's life in her plot to suicide, but ultimately ending in her celebrated transformation and departure from the house.

In the original spatial dramaturgy of the play, the final scene of conversation between Nora and Torvald starkly contrasts their physical interactions up to that point. The two sit still for the first time, opposite each other at a table that has been placed in the center of the room. Ibsen uses all spaces with careful attention to symbols; he marks this conversation as the first of its kind by the center stage location and stillness not yet experienced in the play. In our staging, I marked this change in the way that the audience experienced the space as well. Spectators had remained relatively stationary throughout act 2 , lining the four walls of the real parlor. In the scene preceding the conversation, when Nora changes into her traveling clothes, Torvald delivered his lengthy monologue on the staircase out of view. This drew the audience's attention out of the drawing room space and back into the rest of the house. When Nora reentered the visible space, she sat at the dining room table in a room adjacent to the drawing room. The audience was welcomed to join the actors in this alternate space, thus giving the physical experience of movement toward the end of the play to mirror Nora's own movement and transformation; this also brought audience members close to the 
couple so that they could share in the intimacy of their conversation. The audience was then left deep in the house with Torvald when Nora walked out of the space and the door-slam reverberated in the walls surrounding them to contemplate the "miracle of miracles" that might bring her back.

\section{Reception and Reflections}

The workshop was followed by a discussion between actors and audience members. Predictably, the staging evoked an intimacy, a "fly on the wall" perspective on the material. I was surprised, however, at how much of the post-performance discussion concerned the truth of the offstage space beyond the scene played, out of view. The move into the super-realistic environment extended the boundaries of the fiction beyond the space observed by the audience. The actors spoke of feeling more vulnerable than in a traditional theatre staging, not only onstage while within feet of the observers, but also while offstage, in the real rooms and corridors of the house. "I felt like I was onstage when I was off in the hall waiting for my cue" said Kelsey Hartzell, playing Christine Linde. "I felt like I was performing even while off stage.” Audience members spoke of the effort to integrate the intimate realism they were experiencing in the scenes with the modern reality outside-cars, street sounds, children playing. "I kept putting together what I was hearing inside and out of the house," said one faculty member in the audience. Her imagination attempted to fuse these together, at once generating a Brechtian Verfremdungt on the events of the fictional story, and paradoxically closing the gap between the fiction and the contemporary situation of the event. She related Nora's conflicts to her own in balancing an academic career with family, asking how far we have come in resolving the cultural dilemma that Nora embodied. The unmasked presence of her real professional situation at the university, set immediately alongside the fictional scenes of the play, evoked a closer comparison of the two than typically occurs in a traditional theatre. Thus the offstage space meaningfully enriched the moment of performance for both audience and actor.

The move deeper into the realism expanded the space, pushing its limits offstage to include the actual life surrounding the fiction. Like Scolnicov's argument that the move into the parlor forced the female subject deeper into the space and out of sight, so too we found that the actors' and the audience's interest moved deeper into the unseen parts of the story and unseen parts of the house and the outside real world. When one considers the symbolism of the space in the play itself this is not surprising; indeed, the entire action of $A$ Doll's House concerns the move to leave it, with Nora's departure and door-slam the end result. Given that the action drives out of the space, it is understandable that our interest pushes out of the framed space, as well into what lies beyond it it. ${ }^{9}$

This shift in interest offstage is doubly significant if we also consider that Ibsen uses the space as a metaphor for the theatre. Nora's exit anticipates the move out of the proscenium and the search for means of expressing women's stories more authentically in performance. Further extensions to our experiment suggest going deeper into a "create your own adventure"-type of relation to the story, where the unfolding drama could be experienced from any locale, in view or not of the "main" action. This would prompt filling in and dramatizing the unseen parts of the story, expanding the realism to ever widening circles outward, skewing the traditional relationship of observer/observed and structured story that prompts the gender bias of the gaze.

\section{Spatial Dramaturgy of Fefu and Her Friends}

These considerations became important in our next experiment, a full production of Fornes's Fefu and Her Friends. Discoveries made during the workshop of $A$ Doll's House in relation to offstage space directly impacted the exploration of Fornes's play. In Fefu, Fornes breaks the proscenium line in a number of ways to explore the place between art and life. Her dramaturgical moves were amplified in our experiment, staging the play in a real house and casting nonactors-all real female educators. 
This radically realistic approach enriched the feminism of the script in performance, which, in turn, enhanced the real lives of both the actors involved and the audience.

Like A Doll's House, Fefu is significant in the development of feminist theatre. In his recent book on Fornes, Scott Cummings asserts that "[o]ver time, it became recognized as 'a foundational text in feminist theatre' [Penny Farfan, qtd. in Cummings]. . . . Fefu and Her Friends signaled a[n] ... explicit focus in Fornes's writing on female characters seeking to break free of dependent or oppressive relations with male characters, a shift that lasted for more than a decade and led to Fornes's categorization as a 'woman playwright' and a feminist" (64). Fornes described her inspiration for the play in a spatial metaphor coming, in part, from her experience in a women's group in the 1970s:

At the group I could discuss things I thought all my life. . . But these thoughts were in the "reserve room" because you think there is something odd about feeling that way, especially when we live in a century when women's freedom is absolute. We have public rights, yet we feel these other things. So it kind of serves in a mysterious place and we don't understand it. Something made us not talk about our feelings of this kind of inferiority. We didn't want to recognize our sense of inferiority. (Fornes, qtd. in Fuchs 96)

Set in the 1930s in the New England country house of Stephanie Beckman ("Fefu” for short), a group of female educators meet to plan a fundraiser related to an unspecified aspect of education. Fefu's close friend Julia suffers from a mysterious, crippling illness that began after a hunting accident when a deer (not she) was shot. The dramatic structure is nontraditional: the audience is provided with little more exposition than a fly on the wall in the parlor of Fefu's house, and in the second act, the single-sided audience/actor dynamic is broken, the audience moving around the performance space to watch scenes in different locations, in a different order. This breaks the traditional linearity and cause-and-effect progression of the story and reinforces themes surrounding the indirect ways that we receive information. The significance of environment in relation to education, specifically for women, is explored throughout; for example, a performance of Educational Dramatics by early twentieth-century educator Emma Sheridan Fry, one of several metatheatrical moments woven into the fabric of the play. Quoting Fry, Fefu's friend Emma asks: "What is Environment? Our mate, our true mate that clamors for our reunion." While moments of metatheatricality, combined with the audience's movement into the playing space, suggest such a "reunion" with environment at the present moment of performance, this meeting is meaningfully complicated by the setting in the 1930s. Unlike the realism of Ibsen, Fefu is set at a slight historical remove from its time of writing.

The resonance between Fefu and A Doll's House, and Ibsen's work in general, is meaningful to this larger discussion. A famous anecdote relates that Fornes had only read Ibsen's Hedda Gabler before she began writing plays herself (Robinson 109). While references to Ibsen permeate Fornes's canon, the parallels are most overt in Fefu. In fact, after staging these plays together in the house, I believe that Fefu can be best understood when considered dialogically with Hedda Gabler-Fefu's most profound features a direct extension of Ibsen's realist dramaturgy. The parallels in content between Hedda and Fefu are readily apparent: the central female character in both plays engages in a game in which she shoots a man offstage $;^{10}$ both concern a female character who is trapped "in the dark," envious of men's freedom; both capitalize on the phallic imagery of the guns fired and both conflate creativity with fertility; ${ }^{11}$ and both explore the relationship between exterior and interior spaces in a manner that is significant to the realistic style and theatre in general, particularly for women (Fig. 2).

The scenic parallels between Hedda and Fefu are several. In both, a house is a central symbol. The stage directions in Fefu describe a parlor reminiscent of Ibsen's symbolically encoded box sets, complete with French doors. ${ }^{12}$ While Ibsen's symbols are more overtly utilized than Fornes's, a general conception of space as metaphor runs through Fefu: the interior space is female, the outside male. Elinor Fuchs observes that "Fornes genders the out-of-doors male in Fefu, she genders the interior, with its depth, penetrability, and comfort-its domestic spaces figured as body parts and 


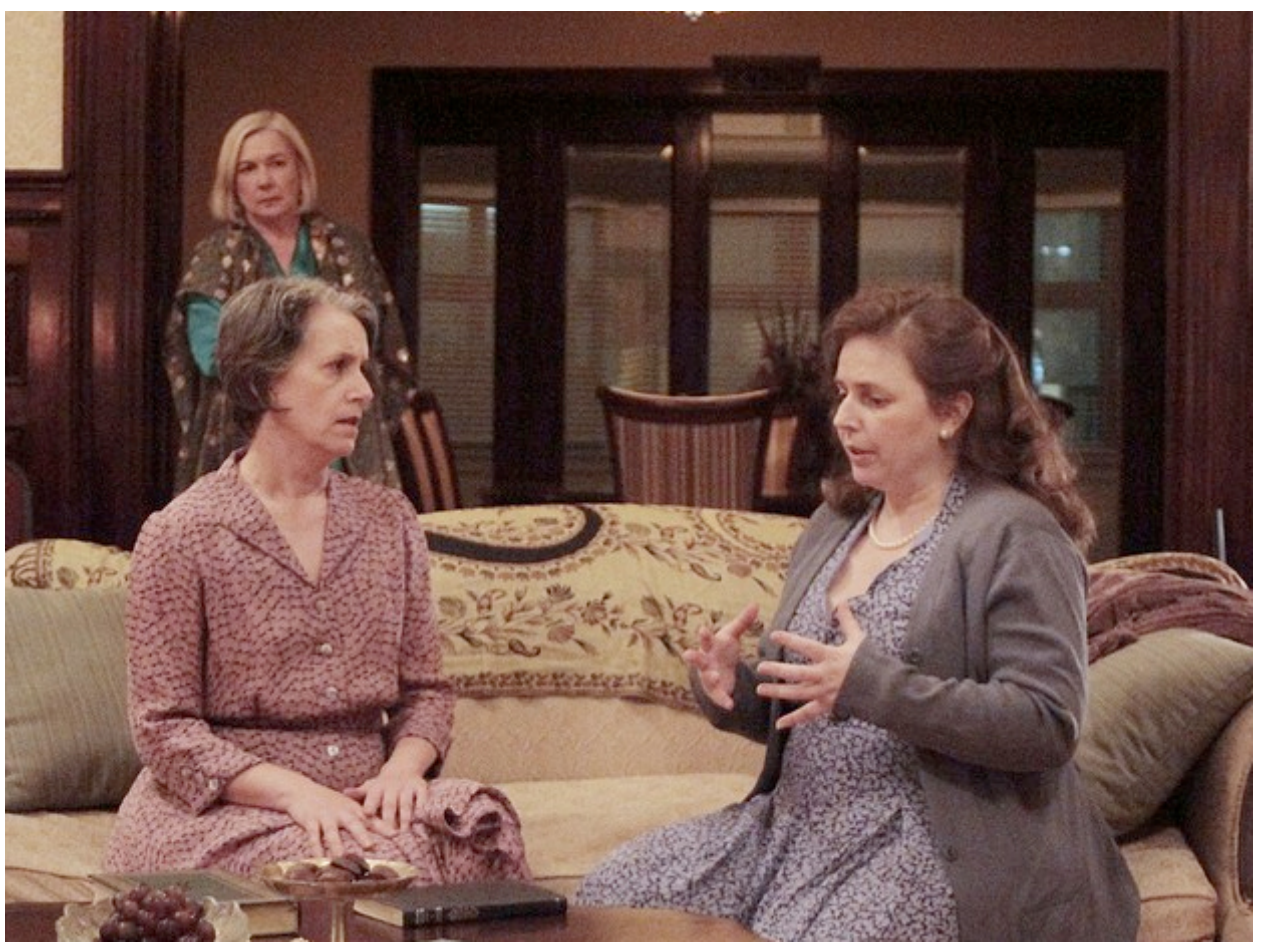

FIG. 2. Part 1 of Fefu and Her Friends in the drawing room of the restored Piper Hall. From left: Bren Ortega Murphy as Fefu (standing), Betsy Jones Hemenway as Christina, and Ann M. Shanahan as Cindy. (Photo courtesy of the Department of Fine and Performing Arts, Loyola University Chicago.)

inner organs-female" (85). This equation extends to the experience of the spectator in part 2. "Not content to merely align her spectators and her actors on facing planes, Fornes now welcomes her audience in the very body of Fefu's house. Like the body and unlike most stage sets the house has depth and scale matched to our own human bodies. ... But beyond such familiar associations, spectators begin to discover something unfamiliar, the specificity of their own bodies in the theater." Fuchs concludes that as a result, "at the level of text, dramaturgy, and reception, the play is embodied. ... Since the actors and I now shared the same 'house,' their bodies became real bodies instead of the stand-ins for the imagined bodies of the characters that most audiences make of actors" (89).

Cummings describes what he considers a particularly successful production of Fefu produced by At the Foot of the Mountain and directed by Fornes herself at an old firehouse in Minneapolis in 1986:

In her characteristic fashion, Fornes directed the play in direct response to the physical site at hand, obscuring the boundary between stage set and theater architecture, between inside and outside, between dramatic event and daily life, creating a volatile liminal zone that at any moment was subject to the demands of either the theater or the street. The production instigated a spectatorial self-awareness that was immediate and thrilling and that strengthened a sense of intimacy and identity with the audience as a whole and with the cast of female characters. (73)

The creation of a "volatile liminal zone" is a useful metaphor for Fornes's overall project in Fefu. Our production at Piper Hall was characterized by a similar approach, and it is in this zone that the significance of the project, by staging in a real house, can be most clearly discerned. 


\section{The Production}

The character of Emma in Fefu declares: "Life is theatre. Theatre is life. If we are showing what life is, can be, we must do theatre." I suggested that the Gender Research Seminar, consisting of faculty teaching in gender studies across the university, perform Fefu because of this connection between art and life. For four years prior to the project the seminar met in Piper Hall one Saturday a month to discuss interdisciplinary topics on gender. At these meetings, gatherings of women related to education, I was consistently reminded of the play. The synchronicity of meeting in the house serving as home to WSGS furthered the connection. Through a special projects grant from the College of Arts and Sciences, the play was performed by eight of the faculty members, including representatives from five schools and centers in the university and several departments in the college in the spring of 2012. Most of the women had no performance background, aside from myself and the woman playing Fefu (Bren Ortega Murphy, a professor in the School of Communication who has a background in performance studies). I played the role of Cindy and also took the lead in the collaborative direction of the play. ${ }^{13} \mathrm{My}$ position, which was simultaneously inside and outside the play, provided valuable insights into the dynamics of the overall project and its occupation of liminal space.

We rehearsed for over three months, three times a week, and performed the play in late March (when we could comfortably utilize the actual entrances of the house). We played three performances to sold-out audiences comprised of students, faculty, staff, family, and friends. We advertised through posters using images of women and Piper Hall during the 1930s from the Gannon Center archives. The production was professionally designed and fully staged. Audiences lined the four walls of the parlor in parts 1 and 3, and broke into four groups of approximately fifteen to watch the scenes in a library, pantry, makeshift bedroom, and sunroom in part 2 (Fig. 3).

\section{Reception and Reflections}

Both Cummings and Fuchs articulate the connectedness and embodiment that emerge from the spatial dramaturgy of the play and the movement of its audience. These features were amplified and expanded in our project by staging in a real house with nonactors-real friends and colleagues with relationships to both the current use of the house and the university community in which it is situated. We capitalized on the spatial dramaturgy of the play_-its liminal zone-and extended it. The interplay between life and theatre in this zone relates to Fornes's brand of realism, which might be said to start where Ibsen's leaves off. Whereas feminists have argued that traditional realism, founded on restrictive ideologies and practices, may not contain real bodies of women, ${ }^{14}$ in Fefu, Fornes explores how realistic principles might be skewed to create space for female subjects in theatre. She pushes the boundaries of the realistic conceit to border and intersect with real life, loosening the gender biases of the fourth wall and linear structure, expanding the expressive potential onstage for women. Fornes aims to stage "the mysterious place" where authentic, contradictory experience, including women's bodies, can take place.

Significantly, our passport to this space is a significant symbol directly from Hedda Gabler. As Fuchs describes, "[o]f all the scenes in the second act, the scene in the Bedroom moves off the realistic continuum of the play. . . . It is a sunny day in late spring or early summer . . yet in the bedroom—stage directions tell us that it is a bare and unpainted storeroom that has been converted into a sleeping room for Julia - there are dead leaves on the floor" (33). In the first scene of Hedda, Hedda looks outside her French doors. In response to Tesman's question as to what she is looking at, she responds:

HEDDA: Only the leaves they are so golden and withered.

TESMAN: We're already into September now.

Hedda: Yes, we are already into September. 


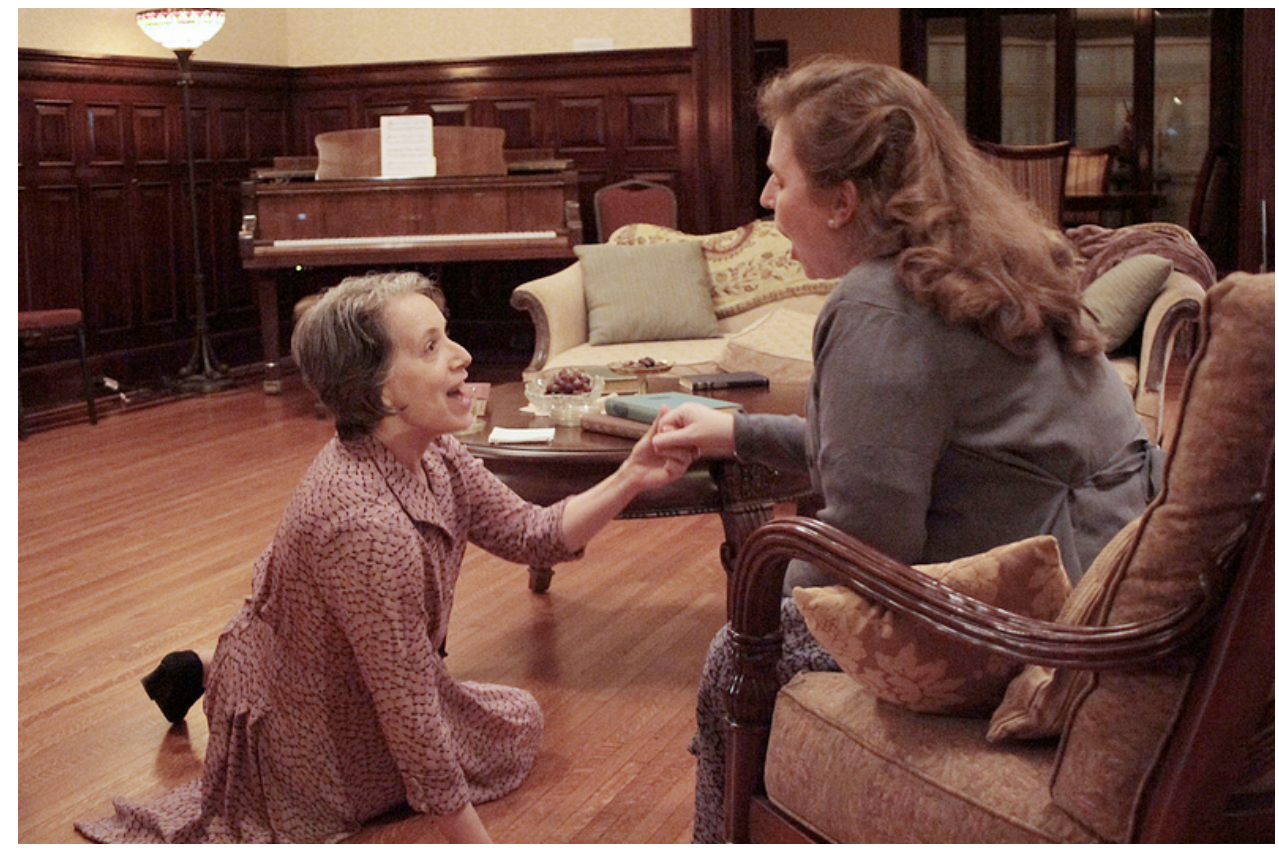

FIG. 3. Ann M. Shanahan (Cindy) and Betsy Jones Hemenway (Christina) sing "Winter Wonderland" in Fefu and Her Friends. (Photo courtesy of the Department of Fine and Performing Arts, Loyola University Chicago.)

This brief conversation, following a moment of frustration for Hedda, sets up an equation between external feature and internal state. Symbolic relationships between realistic setting and character permeate Hedda, and all of Ibsen. This symbolic relationship between things blurs the boundaries between internal and external, real and symbolic. It is fitting that leaves marking the frustration of female power, aging vitality, and the blurring of real and symbol, internal and external, show up in Julia's "storeroom," or Fornes's "reserve room"-that mysterious liminal space where boundaries are broken. Fuchs adds that "[p]utting Julia's hallucination in the form of a soliloquy without an unauthorized observer or receiver is Fornes's chief means of creating its surrealistic effect" (95). As a result of the soliloquy, where spectators are positioned as the imagined "judges" receiving the speech, audience becomes character - its presence acknowledged in the fiction, but then complicated as hallucination.

While the above comparison has been discerned by critics of the plays in performance elsewhere, the scope of interplay between interior and exterior space in Fefu, the intricate poetics of the volatile liminal zone, were not fully clear to me until these performance-based experiments in relation to each other. I now recognize that the blends of realism and symbol, audience and actor, presence and hallucination are connected to the use of space at the end of the play and are crucial to its overall meaning. The ending of Fefu occurs in the volatile liminal zone, which is especially meaningful when contrasted with Ibsen's framed inner rooms and Hedda's entrapment there. After an explosive confrontation with Julia, Fefu goes offstage and fires her gun. Like Hedda, she picks up the gun in an attempt to have some control, some power, but instead of shooting herself indoors, she kills a rabbit (a possible reference to Hedda's pregnancy) outdoors. In response to this shot, the character of Julia, seated indoors in a wheelchair, experiences a head wound and likely death. This ambiguous ending, while tragic, gruesome, and complicated, does not frame and reify cultural norms as does the ending of Hedda, when Judge Brack declares "people don't do such things." In $F e f u$, the group of friends silently encircles the wounded Julia in an unclear though potent gesture situated squarely in the liminal zone. Like the breakdown in the barrier between the symbolic and real, the barrier between internal and external dissolves in this move. 
The effect of this blending was accentuated for audience members in our experiment because they shared the interior space, bordered by real architecture, with Julia. Situating the audience in the house implicated them in meaning-making and intensified the experience around the play's final symbol. Paradoxically, as the exterior wall had been symbolically dissolved, the events dramatized inside the house were more connected to the real life of the university campus surrounding it. Ultimately, as with A Doll's House, the shared situation inside the domestic architecture of the house amplified the culmination of the play's actions as they relate to interior and exterior spaces and connected the fiction of the play to the outside world (Fig. 4).

By far, the dominant effect of the performance project for me was the development of palpable connections to the women of the cast, to the space of Piper Hall itself (and its history), and to the students and faculty who came to the play as audience members. I believe that this sense of connectedness came from this breakdown of boundaries - namely, life/theatre, spectator/actor, interior/ exterior, reality/fiction - inherent in the play and its suggested spatial dramaturgy, and then was furthered by the dynamics of our project. This breakdown in boundaries was intensified by the fact of staging in a materially real space, with real function in the present and with a real history, both domestic and educational, for women. Not only were we made aware of the materiality of female bodies in the material house, including our own, but we were also made aware of the bodies that had occupied the space in the past. While rehearsing and performing, I found myself thinking of the woman who designed the space and the women who had occupied it when it served as Mundelein College's library. Performing the role of Cindy with my colleague Betsy Jones Hemenway (the director of WSGS) playing Christina in part 2, I recounted a dream, one of several monologues based on art/hallucination in this section. As I actively visualized the progression of the dream narrative, I saw it occurring in the real library in which I was sitting; running to catch a taxi, I pictured myself leaving the front door of Piper Hall to a car running along Sheridan Road, which curves just outside. As I imagined this fiction in the reality I saw, I thought of photographs I had seen of this location in the 1930s and also of the women of that time who had looked out upon this same scene that was before me now. As I had never done before, I identified with their perspective through occupying their identical physical situation. This fusion of fiction and reality in relation to the space and its former female occupants happened continually throughout the rehearsal and performance process. I believe that this awareness was prompted by performing a play that blurs boundaries from another period in an actual setting that functions in the present day, but which has a history dating back to the historical period of the play's story. By occupying the house from the point of view of a woman in another time, I dwelt in the space that held women's lives (and bodies) in the past (Fig. 5).

These considerations further illuminate the significance of Fornes's setting for the play. In the spirit of early realism, Ibsen sets his play in his contemporary "present" of the late nineteenth century. Staging the play in the present, we only experience a singular layer of historical remove between our time and the play's setting. Fornes places her story in the 1930s, which is at a remove from the time of its writing, in 1977. This added layer of historical remove, especially when combined with a performance in the twenty-first century, intensified the liminality of the overall experience to include an affect similar to Brecht's historification of setting. The result, while distancing us from any single period, allows several historical realities to exist simultaneously-a kind of not-but of historical placement, which provides space for several alternatives at once rather than a singular inevitable outcome or story line/fiction. ${ }^{15}$

My fellow cast members with faculty appointments in history had similar observations. Betsy Hemenway wrote in her postmortem:

For some of us, Piper Hall was our regular work space which at times became our performance space, rendering the boundary between daily life and performance more porous. Our daily existence intersected with rehearsal routines, and personal triumphs, dramas, and challenges entered our common space. So we shared those things too, providing community and support 


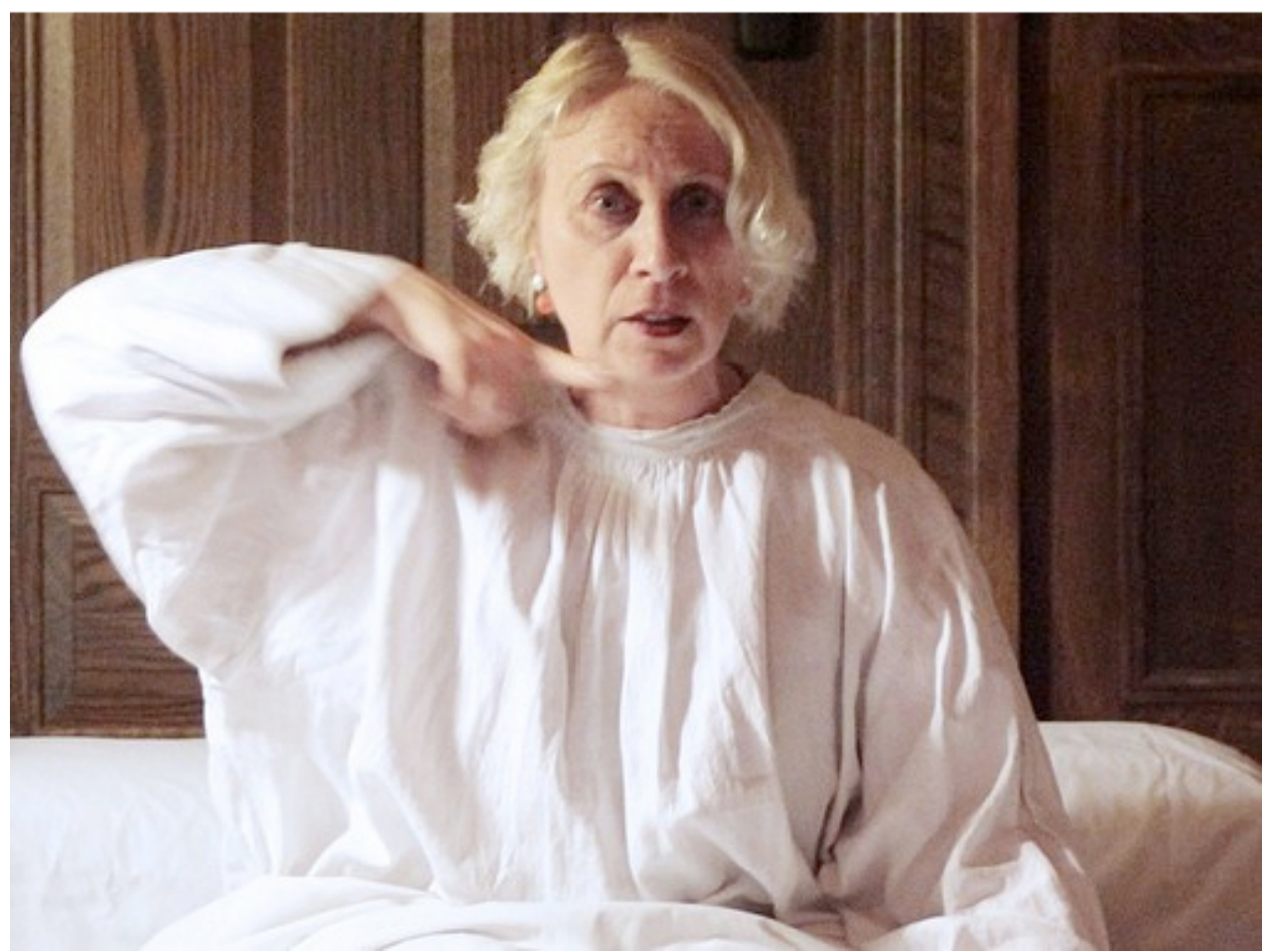

FIG. 4. Jacqueline Long as Julia speaks to the audience in the bedroom in part 2 of Fefu and Her Friends. (Photo courtesy of the Department of Fine and Performing Arts, Loyola University Chicago.)

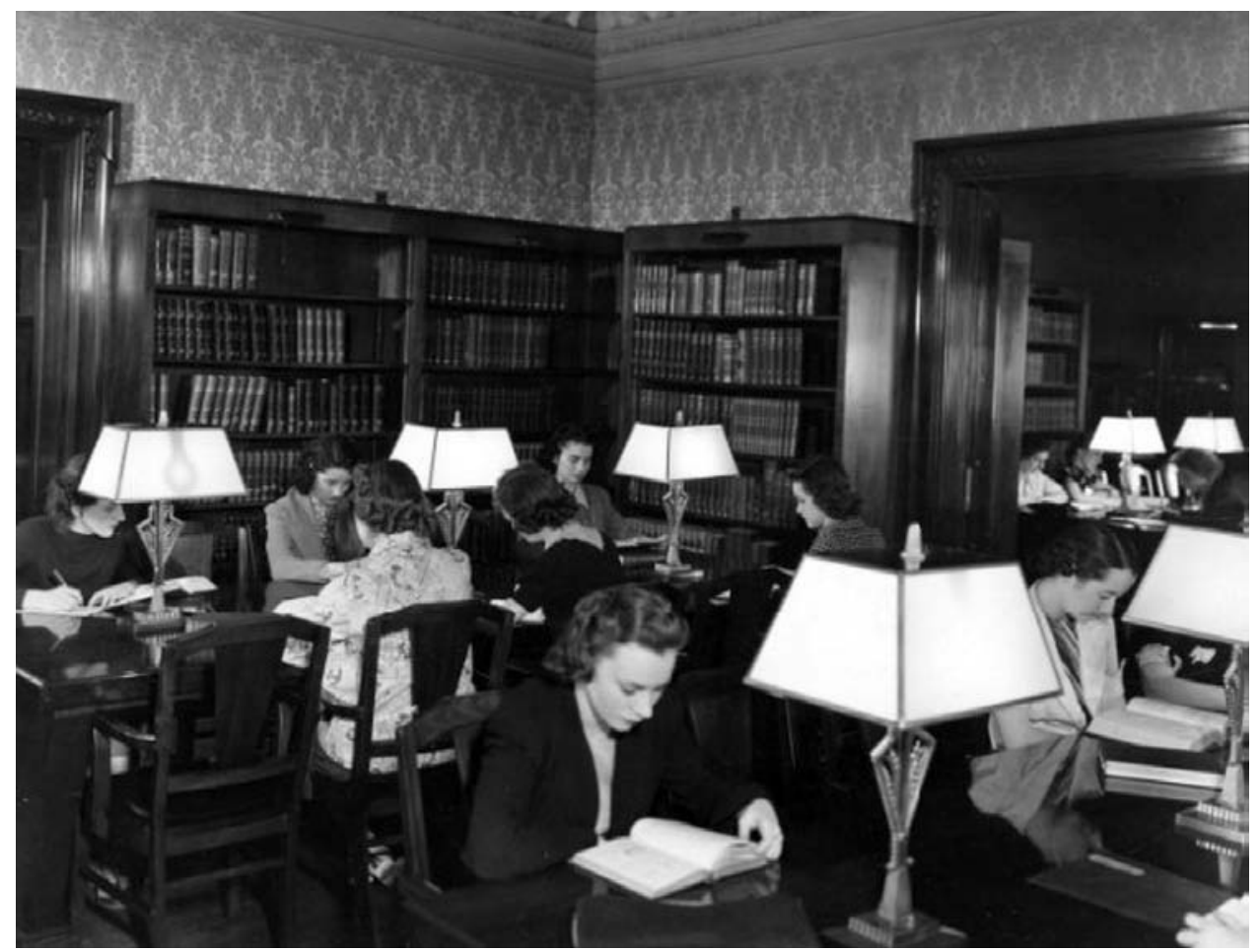

Fig. 5. Women in the library of Mundelein College in 1938. (Photo courtesy of the Women and Leadership Archives, Loyola University Chicago.) 
for one another. In crossing the boundaries of theatre and "life," we developed empathy and deeper connections with one another, making our abstract knowledge of women's history more concrete and embodied. Theatre and performance, therefore, has become for us a way to cross boundaries between history, daily practice, and inner struggle and growth.

Her colleague in history, Prudence Moylan, wrote:

I would say that performing has given me a more integrated sense of how my personal and social memories shape my life and work. In Fefu we have a play of the 1970s reflecting on the roles of men and women through a 1930s perspective on gender performance. As a person who was born in 1939, earned a History Ph.D. in 1975 and performed this play in 2012 on the cusp of retirement I was happily surprised to find a new integration and transformation of personal, professional and social memories.

Several cast members observed that the project had impacted their perspectives on their own fields, other disciplines, and teaching. Jacqueline Long, playing Julia, observed: "The embodied experience of performing Fefu is a valuable reminder for a Classicist that the past we conjure in scholarly imagination was embodied in its own reality, too. I strive to challenge my students with the fact that our texts bespeak a world." Then, quoting her character, "Hallucinations are real, you know." And Murphy observed that

I learned a number of things by performing Fefu's performance. In terms of teaching, this experience has confirmed my belief that performance is a powerful teacher. I have recently begun to have students in certain classes use performance of play excerpts and children's books as a way to learn core concepts ... this approach comes from the performance studies precept that using your entire body to contend with ideas deepens your understanding in a way that mere reading cannot.

Performing Fefu was a deeply interdisciplinary endeavor, involving activities outside the fields of most of the participants. Because of this, we were allowed to see ourselves, particularly ourselves in relation to our genders and our bodies in space and community, in new ways. We positioned ourselves outside the norms of our disciplines, revealing new truths.

\section{Conclusions}

In the same way that staging A Doll's House in real architecture drew interest off the "stage" and into the surrounding reality, so also in Fefu and Her Friends, our interest was drawn to the real world running alongside the fiction of the play, and the interplay between the two. In both cases, staging in a house increased the connectedness of the performance event to the world surrounding it- theatre to life. I did not know when I embarked on these projects that these would be the results. In retrospect, I believe that this came from staging a play that breaks boundaries in a space with a real function for, and history of, women's bodies_-in which Woolf reminds us that "the very walls are permeated [by women's] creative force." These dynamics of domestic spaces collude with other techniques, such as breaking the fourth wall, to allow material bodies into the spaces, thus making undeniable the reality of women's bodies both onstage and off. Staging plays with a historical setting in a house with an actual history contextualizes the fiction of the plays in ways that allow for the materiality of performer and audience, as well as for referencing the women's bodies that related to that architecture in the past. This experience suggests that performance in real settings (perhaps also using "real people," as opposed to actors) may offer sociologists, anthropologists, and historians a new method of inquiry that encounters the materiality of bodies in history, particularly those of women. 
The combined results of these two experiments include the observation that feminist dramaturgy commonly draws toward the boundaries between outside and inside, art and fiction. Both playwrights direct the action of their plays toward these boundaries. This open barrier, or liminal space, is one place where women's stories can be told and women's bodies in dramatic renderings exist. Significant to the paradigm of practice-based research, this space can only be fully discerned through experience-occupation of the physical act of performance as either audience member or actor. Because our performance of Fefu in a real house with nonactors was situated between the real and the fictitious on multiple levels, liminal space was richly occupied in the project. While the push to break boundaries is inherent in the plays themselves, its epistemological value could be more fully manifest in spaces shared by audience and performer, with a real function in relation to women, history, and education. Feminist research, which seeks to link theory to practice, is situated in this volatile liminal zone, thus naturally suited to practice-based research, especially in performances like ours that link art to real settings.

The workshop of $A$ Doll's House and staging of Fefu and Her Friends are part of an ongoing set of experiments on performance, gender, and space at the Gannon Center and the Gender Research Seminar. Our playing in the house amounts to a sort of search for the room of Nora's own, an effort to open the "reserve room" that Fornes spoke of during the 1970s, with site-specific staging in a house serving as one of several tactics to expand space for female subjects in performance. Through a combination of techniques and experiments and drawing on writers' reflections on the relation of women to houses throughout history, staging in an actual house can help us to move closer to hearing the sound of footsteps in the inner room of artistry and scholarship on women and performance.

\section{Acknowledgments}

Warm thanks to the College of Arts and Sciences, Women's Studies and Gender Studies Program, and the Gannon Center at Loyola University Chicago for generously supporting these events. Thanks also to Gannon director Janet Sisler (who also played Emma in Fefu); Carol Coyne for her patient facilitation of the space; Beth Myers for use of the archives; student actors Weatherly Marshall, Austin Cornett, Kelsey Hartzell, Chris Thompson, Timothy Bertucci, Claire Bader, and Annie Murphy; faculty actors (not named above) Susan Grossman (professor, School of Social Work) and Mary Dominiak (assistant professor, School of Nursing); dramaturge Hector Garcia (instructor, Department of Modern Languages and Literatures); assistant director and stage manager Bernadette Raspante; Janice Pytel (costumes); and Emma Deane (properties and sound).

Ann M. Shanahan is an associate professor of theatre at Loyola University Chicago, where she teaches courses in performance and text analysis. She is an associate faculty member with the WSGS program, and a member of the Gender Research Seminar. Shanahan has directed numerous productions at Loyola, and her professional directing credits include The Vagabond and The Turn of the Screw for City Lit Theater Company and On Golden Pond, Lies \& Legends, Wasp, Warrior, and The Living for Buffalo Theatre Ensemble. She recently served as dramaturge at Rivendell Theatre Ensemble. Shanahan has published in Theatre Journal, Text and Presentation, and Theatre Topics, and has presented numerous papers on acting and directing pedagogy at the Comparative Drama Conference and the Association for Theatre in Higher Education, where she serves as Focus Group Representative for the Directing Program. She is a recipient of the Drama League of New York Directing Fellowship and holds a BA in drama from the University of Michigan and an MFA in directing from Northwestern University. 


\section{Notes}

1. In the summer following the production of Fefu, WSGS was asked to move its main operation out of Piper Hall, although several events are still held there in conjunction with the Gannon Center, which remains. At our most recent event in the space, Bren Ortega Murphy (Fefu) commented how, because of the play, it still feels like she "lives" there.

2. "The Yellow Wallpaper" is Gillman's autobiographical story about a woman who battles neurasthenia, the "female malady" of the nineteenth century. Prescribed a "rest cure" in a country house, she begins to perceive the figure of a woman trapped behind wallpaper in the nursery that has been made her bedroom. The woman discovers in the end that the woman trapped behind the paper is, in fact, herself. Gillman's recovery from her own depression and nervous collapse following the birth of a child marked the initiation of her literary career and work as a lecturer and activist for women's rights.

3. Edith Wharton coauthored The Decoration of Houses with architect Ogden Codman in 1897. This book applies European design principles to recommendations for interior design. Wharton also wrote Italian Villas and Their Gardens (1904).

4. Her title, The House of Mirth, comes from the biblical passage, "The heart of the wise is in the house of mourning; but the heart of fools is in the house of mirth" (Ecclesiastes 7:4). Wharton depicts the New York high society of the time as this "house of mirth," and her heroine Lily Bart dies by her adherence to the hypocritical morals of its culture for women.

5. From Dennis Krausnick's play The Inner House, which, in part, is from Wharton's 1934 A Backward Glance. The Inner House was presented by the Wharton Salon at the Stables Theatre in Lenox, Massachusetts, in 2012.

\section{See Philip Thompson and Peter Davenport, The Dictionary of Graphic Images.}

7. A few of the many sources for feminism and theatre are: Gayle Austin, Feminist Theories for Dramatic Criticism; Sue-Ellen Case, "Classic Drag: The Greek Creation of Female Parts" and Feminism and Theatre; and Jill Dolan, The Feminist Spectator as Critic.

8. Caryl Churchill's Top Girls and Cloud Nine are famous examples of nonlinear play structures and double casting, among other feminist tactics to break a male gaze.

9. Thanks to Ellen Dolgin for pointing out that the symbolism of the space in the original play would impact the audience's reaction to the space in the setting of the house, and that this might account for the actor/ audience interest in the offstage space.

10. Another of several sources for Fefu's game with the rifle is a Mexican joke, as Fornes relates: "There are two Mexicans speaking at a bullfight. One says to the other, 'She is pretty, that one over there.' The other one says, 'Which one?' So the first one takes his rifle and shoots her. He says, 'That one, the one that falls'” (Fornes and Creese 1977, 30).

11. Hedda kills the "child" of Eilert when she burns the manuscripts and kills her pregnant self. Fefu kills a rabbit in the end, a symbol of fertility.

12. Hedda Gabler, stage description, act 1: "The opposite wall, on the left, contains French windows" (153); Fefu's stage description: "French doors leading to a terrace...." 
13. The cast of Fefu preferred to work in a mix of traditional and collaborative feminist models of directing. This mélange, which falls outside the purview of this essay, was required largely by time constraints.

14. For a précis of related feminist theories on feminine morphology in realism, see Case, Feminism and Theatre, 127-29, which references Hélène Cixous's "The Laugh of the Medusa."

15. Brecht's practice of setting contemporary conflicts at a distance of either time or place has been called historification - part of a larger project in distancing the audience from dramatized events so that they may be considered critically. The principle of not-but is a technique of acting that allows the audience to see not only the option taken, but also the alternatives not chosen ("not this, but that").

\section{Works Cited}

Austin, Gayle. Feminist Theories for Dramatic Criticism. Ann Arbor: U of Michigan P, 1990.

Bachelard, Gaston. The Poetics of Space: The Classic Look at How We Experience Intimate Places. Boston: Beacon Press, 1994.

Case, Sue-Ellen. "Classic Drag: The Greek Creation of Female Parts.” Theatre Journal 37.3 (1985): 317-27.

- Feminism and Theatre. New York: Routledge, 1988.

Cixous, Hélène. “The Laugh of the Medusa." Trans. Keith Cohen and Paula Cohen. Signs: Journal of Women in Culture and Society 1.4 (1976): 875-93.

Cummings, Scott T. Maria Irene Fornes. Abingdon, UK: Routledge, 2013.

Dolan, Jill. The Feminist Spectator as Critic. Ann Arbor: U of Michigan P, 1988.

Fornes, Maria Irene. Fefu and Her Friends. New York: PAJ Publications, 1978. and Robb Creese. “I Write These Messages That Come." TDR: The Drama Review 21.4 (1977): $25-40$.

Fry, Emma Sheridan. Educational Dramatics. New York: Lloyd Adams Noble, 1917.

Fuchs, Elinor. "Fefu and Her Friends: The View from the Stone." The Theater of Maria Irene Fornes. Ed. Marc Robinson. Baltimore: Johns Hopkins UP, 1999. 85-108.

Gillman, Charlotte Perkins. "The Yellow Wallpaper." Herland and Selected Stories. New York: Signet Classic, 1992.

Ibsen, Henrick. A Doll's House. The Plays of Ibsen. Trans. Michael Meyer. New York: Washington Square Press, 1986.

. Hedda Gabler. The Wild Duck and Hedda Gabler. Trans. Michael Meyer. New York: W. W. Norton, 1997.

Robinson, Marc. "The Summer in Gossensass: Fornes and Criticism." The Theater of Maria Irene Fornes.

Ed. Marc Robinson. Baltimore: Johns Hopkins UP, 1999. 109-29. 


\section{Ann M. Shanahan}

Scolnicov, Hanna. Woman's Theatrical Space. Cambridge: Cambridge UP, 1994.

Thompson, Philip, and Peter Davenport. The Dictionary of Graphic Images. New York: St. Martin's P, 1981.

Wharton, Edith. A Backward Glance. New York: D. Appleton-Century, 1934.

The House of Mirth (1905). Reprint, New York: Signet Classics, 2000.

Woolf, Virginia. A Room of One's Own (1929). Reprint, London: Penguin Books Ltd, 1963. 